Canadian Journal of Higher Education Revue canadienne d'enseignement supérieur

Volume 43, No. 3, 2013, pages $56-77$

\title{
Investigating the role of mobile devices in a blended pre-service teacher education program
}

\author{
Norman Vaughan \\ Mount Royal University \\ Kimberley Lawrence \\ University of Calgary
}

\begin{abstract}
The purpose of this research study was to investigate if and how mobile devices could be used to support the required program outcomes in a blended pre-service teacher education degree. All students enrolled in an educational technology course during the fall 2011 semester were provided with ViewSonic tablets. Through faculty interviews, student online surveys, and a postcourse focus group, the study participants indicated that mobile devices could be useful for supporting future professional responsibilities (e.g., career-long learning, collaboration) and facilitating student learning but less effective for planning, assessment, and managing the classroom environment.
\end{abstract}

\section{Résumé}

Le but de la présente étude était d'analyser si les appareils mobiles pouvaient être utilisés pour appuyer les résultats des programmes requis d'une formation initiale mixte en éducation pour futurs enseignants et, le cas échéant, comment. Ainsi, tous les étudiants inscrits à un cours de technologie de l'éducation durant la session d'automne 2011 ont reçu des tablettes Dell et ViewSonic. Par le truchement d'entrevues avec le corps professoral de la faculté, des sondages en ligne menés auprès d'étudiants et d'entretiens avec 
un groupe de discussion après la formation, les participants de l'étude ont indiqué que les appareils mobiles pouvaient être utiles pour appuyer leurs responsabilités professionnelles à venir (comme l'apprentissage continu et la collaboration entre collègues au fil de leur carrière) et faciliter l'apprentissage des étudiants, mais qu'ils sont moins efficaces pour la planification, l'évaluation et la gestion d'une salle de classe.

The idea of blending different learning experiences has been in existence ever since humans started thinking about teaching (Williams, 2003). What has recently brought the term blended learning into the limelight is the infusion of web-based technologies into the learning and teaching process (Allen \& Seaman, 2010; Clark, 2003). These technologies have created new opportunities for students to interact with their peers, teachers, and content.

Blended learning is often defined as the combination of face-to-face and online learning (Sharpe, Benfield, Roberts, \& Francis, 2006; Williams, 2002). Ron Bleed, the former vice chancellor of information technologies at Maricopa College in Arizona, argues that this is not a sufficient definition for blended learning as it simply implies "bolting" technology onto a traditional course, using technology as an add-on to teach a difficult concept or adding supplemental information. He suggests that instead, blended learning should be viewed as an opportunity to redesign the way that courses are developed, scheduled, and delivered through a combination of physical and virtual instruction, "bricks and clicks" (Bleed, 2001). The goal of this redesigned approach to education should be to join the best features of in-class teaching with the best features of online learning to promote active, self-directed learning opportunities for students, with added flexibility (Garnham \& Kaleta, 2002; Littlejohn \& Pegler, 2007; Norberg, Dziuban, \& Moskal, 2011). This sentiment is echoed by Garrison and Vaughan (2008), who state that "blended learning is the organic integration of thoughtfully selected and complementary face-to-face and online approaches and technologies" (p. 148). While there are no statistics available for the growth of blended learning in Canadian higher education institutions (Matheos, 2011), a survey of e-learning activity in the United States by Arabasz, Boggs, and Baker (2003) found that $80 \%$ of all higher education institutions and $93 \%$ of doctoral institutions offer hybrid or blended learning courses. Potentially, a similar trend may also be present in Canada.

Most of the recent definitions for blended courses indicate that this approach to learning offers potential for improving the manner in which we deal with content, social interaction, reflection, higher-order thinking and problem solving, collaborative learning, and more authentic assessment in higher education (Graham, 2006; Mayadas \& Picciano, 2007; Norberg et al., 2011). Dziuban and Moskal (2013) further suggest that "blended learning has become an evolving, responsive, and dynamic process that in many respects is organic, defying all attempts at universal definition" (p. 16). For the purpose of this research study, blended learning is defined as the intentional integration of classroom and field-based learning experiences through the use of digital technologies such as mobile devices (Figure 1). 


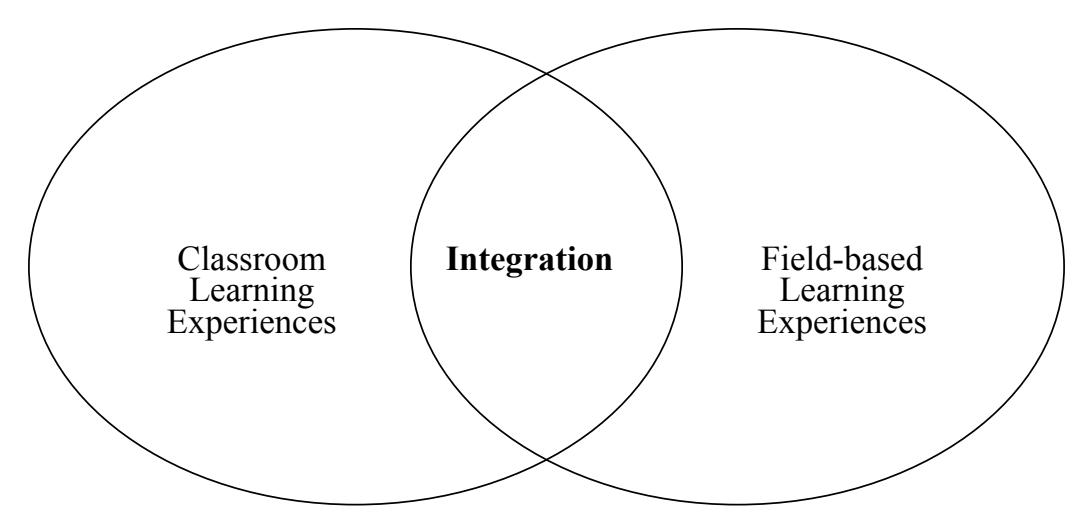

Figure 1. Pre-service teacher education approach to blended learning

There have been a variety of definitions used for the concept of mobile learning. It has been suggested by Brasher and Taylor (2005) that mobile learning is "any sort of learning that happens when a learner is not at a fixed, predetermined location, or learning that happens when the learner takes advantage of the learning opportunity offered by mobile technologies" (p. 33). The Mobile Learning Network (2013) in the United Kingdom states that mobile learning is "the exploitation of ubiquitous handheld technologies, together with wireless and mobile phone networks, to facilitate, support, enhance and extend the reach of teaching and learning". Ally (2009) indicates that M-learning focuses on the delivery of electronic learning materials, with built-in learning strategies, on mobile computing devices to allow access from anywhere and at any time, while E-learning involves the delivery of electronic learning materials on desktop and notebook computers. And the EDUCAUSE Learning Initiative (Brown \& Diaz, 2010) attempts to create classifications for mobile learning based on the size of the device. For example, highly mobile devices are cellphone-sized devices that can fit in a pocket: feature phones (supporting cell and SMS service only), smartphones, and other devices like Flip cameras. Very mobile devices are slates, pads, and netbooks. Mobile devices are larger devices such as laptops. This classification system was utilized in this study in order to differentiate the affordances that different sizes and types of mobile devices have to support the required program outcomes in a blended pre-service teacher education degree.

There have been previous research studies about the use of mobile devices in higher education (Gikas \& Grant, 2013; West, 2012; Zhu, Kaplan, Dershimer, \& Bergom, 2012). These studies have primarily investigated the advantages and disadvantages of using these devices in university courses, whereas this study focused on how mobile computing technologies could be used to support program learning outcomes in a pre-service teacher education program.

\section{Study Context}

The blended pre-service teacher education program described in this study takes place at Mount Royal University, a four-year undergraduate institution in Calgary, Alberta, Canada (http://www.mtroyal.ca/). A new bachelor of education (BEd) program was launched in the fall of 2011 (http://www.mtroyal.ca/bed/). This is a four-year direct entry BEd degree. The emphasis of this program is on connecting theory with practice through 
early, consistent, and ongoing field experiences. In the first two years of the program, students have a core education course each semester that meets once a week and is linked to a 20- or 30-hour field placement. In the third and fourth years of the program, the students have extended field placements that are connected to program-of-studies courses and a capstone experience that are designed to integrate theory (of the coursework) and practice (of the field experiences) (Table 1).

Table 1

Bachelor of Education Field-Based Learning Experiences

Volunteer field placements

$\begin{array}{ll}\text { Year one } & \text { Fall semester: } 30 \text { hours } \\ & \text { Winter semester: } 30 \text { hours }\end{array}$

Year two Fall semester: 20 hours

Winter semester: 20 hours

Practicum placements

Year three $\quad$ Five-week practicum combined with four program-of-studies courses

Year four Nine-week practicum combined with four program-of-studies courses and a capstone experience course

The purpose of this research study was to investigate whether and how mobile devices could be used to support the required program outcomes in this blended pre-service teacher education degree. All students enrolled in an educational technology course during the fall 2011 semester were provided with a ViewSonic Dell ViewSonic tablet. Faculty interviews, student online surveys, and a post-course focus group were conducted as part of this investigation. The following two questions were used to guide this study:

1. What kind of mobile devices do students and faculty currently own and what kind of applications do they use on these devices?

2. How do students and faculty perceive that these devices can be used to support the required program outcomes in a blended pre-service teacher education degree?

\section{Theoretical Framework}

The literature on community of practice and social learning theory informed the methodology and methods of this study. The perspective of learning as increasing participation in communities of practice is embedded in a relational and situated understanding of knowledge (Lave \& Wenger, 1991). This social theory of learning defines communities of practice as "a set of relations among persons, activity, and world, over time and in relation with other tangential and overlapping communities of practice" (p. 98).

Wenger (1998) links the formation of a community of practice with three participatory dimensions: engagement, accountability, and negotiation. Engagement is dependent on developing an understanding of how to interact with other people within the community 
such as students and faculty in pre-service teacher education program. Becoming accountable to an enterprise, for example a set of program outcomes, prompts members to consider certain possibilities that contribute to aligned perspectives of the world. Wenger refers to negotiation as the ability to interpret and make use of a repertoire of the community's practice. In the context of this study, this involved practice, discussion, and reflection on how mobile devices could be used to support the program outcomes for a BEd degree.

In recognition of the connection between learning and the formation of a community of practice, an action research methodology was utilized.

\section{Methods of Investigation}

An action research method (Stringer, 2007) was adopted to investigate how digital technologies could support student assessment in higher education. There are various forms of action research, and the framework defined by Gilmore, Krantz, and Ramirez (1986) was utilized:

Action research... aims to contribute both to the practical concerns of people in an immediate problematic situation and to further the goals of social science simultaneously. Thus, there is a dual commitment in action research to study a system and concurrently to collaborate with members of the system in changing it in what is together regarded as a desirable direction. Accomplishing this twin goal requires the active collaboration of researcher and client, and thus it stresses the importance of co-learning as a primary aspect of the research process. (p. 161)

In addition, Stringer (2007) indicates that action research is a reflective process of progressive problem solving led by individuals working with others in teams or as part of a "community of practice" to improve the way they address issues and solve problems. This research approach should result in some practical outcome related to the lives or work of the participants, which in this case is the effective use of mobile devices in future K-to-12 teaching practice.

There have been concerns about the validity of this methodology, as it is often carried out by individuals who are interested parties in the research (i.e., faculty members) and thus potentially biased in the data gathering and analysis (Pine, 2008). The justification for action research counters this criticism by suggesting that it is impossible to access practice without involving the practitioner. Practice is action informed by values and aims, which are not fully accessible from the outside. Practitioners may not even be wholly aware of the meaning of their values until they try to embody them in their action (Kemmis, 2009).

This approach consisted of a mixture of quantitative (i.e., survey) and qualitative (i.e., interviews and focus group) research methods.

\section{Data Collection}

The principal researcher for this study was also the educational technology course instructor; therefore, data were collected by an undergraduate student research assistant (USRA) in order to minimize perceptions of coercion and bias. The USRA invited all students enrolled in the course to be part of this research project, and a total of 14 students 
participated in this study (100\% response rate). In addition, she invited all the faculty members in the pre-service teacher education program to participate in a 30-minute interview on the topic of mobile learning $(n=6)$. The project received institutional ethics approval, and the students and faculty members signed an informed consent form. The consent form offered the participants confidentiality and the ability to withdraw from the study at any time.

The data collection process began with a pre-course online survey that was designed by the principal researcher and has not been validated statistically (Appendix A). The purpose of this survey was to collect baseline data about what kind of mobile devices students currently owned and what kind of applications they used on their devices, as well as determining students' initial perceptions about how these devices (tablets in particular) could be used to support the required program outcomes of the pre-service teacher education degree. The survey consisted of a mixture of Likert-scale and open-ended questions, and the second version of the online Free Assessment Survey Tool (http://toofast. ca) was utilized.

The faculty interviews were also conducted at the beginning of the fall 2011 semester, and the questions were identical to those used for the student pre-course online survey (Appendix B). These 30-minute face-to-face interviews took place in each of the faculty members' offices. Each of these interviews was facilitated, recorded, and transcribed by the USRA.

Throughout the semester the student participants engaged in a series of learning activities that required the use of their Dell ViewSonic tablets. For example, the students used their tablets to create a lesson plan, video-record a group teaching demo, provide audio assessment feedback to one of their peers, and develop an online tutorial about an Apple or Android app for educational purposes. After each learning activity, the students were encouraged to post their reflections to a research wiki on mobile devices (http:// tinyurl.com/mobileresearchwiki).

At the end of the semester, the students were asked to complete a post-course online survey about their perceptions of how mobile devices could support the required program outcomes in the pre-service teacher education degree as well as their recommendations and strategies for effectively using mobile devices in the program. The students were also invited to participate in a 30-minute post-course focus group with the USRA to discuss the online survey and research wiki findings. Eight students volunteered for this focus group, and the session was digitally recorded and transcribed by the USRA.

\section{Data Analysis}

A constant comparative approach was used to identify patterns, themes, and categories of analysis that "emerge out of the data rather than being imposed on them prior to data collection and analysis" (Patton, 1990, p. 390). The pre- and post-course student online survey results were exported into MS Excel for descriptive statistical and thematic analysis by the USRA and the course instructor. The faculty interviews were transcribed in MS Word by the USRA. The survey data were correlated with the faculty interview responses throughout the semester. At the end of the semester, a preliminary report was compiled and emailed to each of the student participants, who were then invited to participate in a post-course focus group to discuss the initial study findings. The transcript 
from this focus group was reviewed and compared with the student survey and faculty interview data in order to triangulate the themes and patterns.

\section{Findings}

This section begins with a demographic profile of the student participants, followed by a summary of the results for each of the two research questions:

1. What kind of mobile devices do students and faculty currently own and what kind of applications do they use on these devices?

2. How do students and faculty perceive that these devices can be used to support the required program outcomes in a blended pre-service teacher education degree?

\section{Demographic Profile of Student Participants}

In order to establish a context for the study findings, the pre-course survey asked a series of demographic questions. The demographic profile of the students is summarized in Table 2.

Table 2

Survey Respondent Demographics

\begin{tabular}{lc}
\hline Item & Percentage/Number \\
\hline Off-campus accommodation within driving distance & $100 \%$ \\
(57\% lived with their parents) & \\
24 years of age or less & $100 \%$ \\
Employed (part-time 79\%; full-time 0\%) & $79 \%$ \\
Female & $86 \%$ \\
Second year of studies & $94 \%$ \\
Average number of courses enrolled in/semester & 4 \\
\hline
\end{tabular}

The majority of respondents were second-year students who were employed on a parttime basis, commuted to campus, and lived at home with their parents. Respondents were all under the age of 25 , and approximately $86 \%$ percent were female. The demographic profile of student participants reflects that of the university as a whole with respect to age, employment status, residence, and level of course enrolment, with the exception of gender (Prairie Research Associates, 2011). Approximately two-thirds of the Mount Royal University student population is female, and the higher percentage of females in this study is due to a higher concentration of female students in our bachelor of education program.

\section{Student and Faculty Ownership and Use of Mobile Devices}

At the beginning of the fall 2011 semester, students and faculty were asked to identify what types of mobile devices they owned and what kind of applications they used on these devices. The results are highlighted in Figures 2 and 3. 


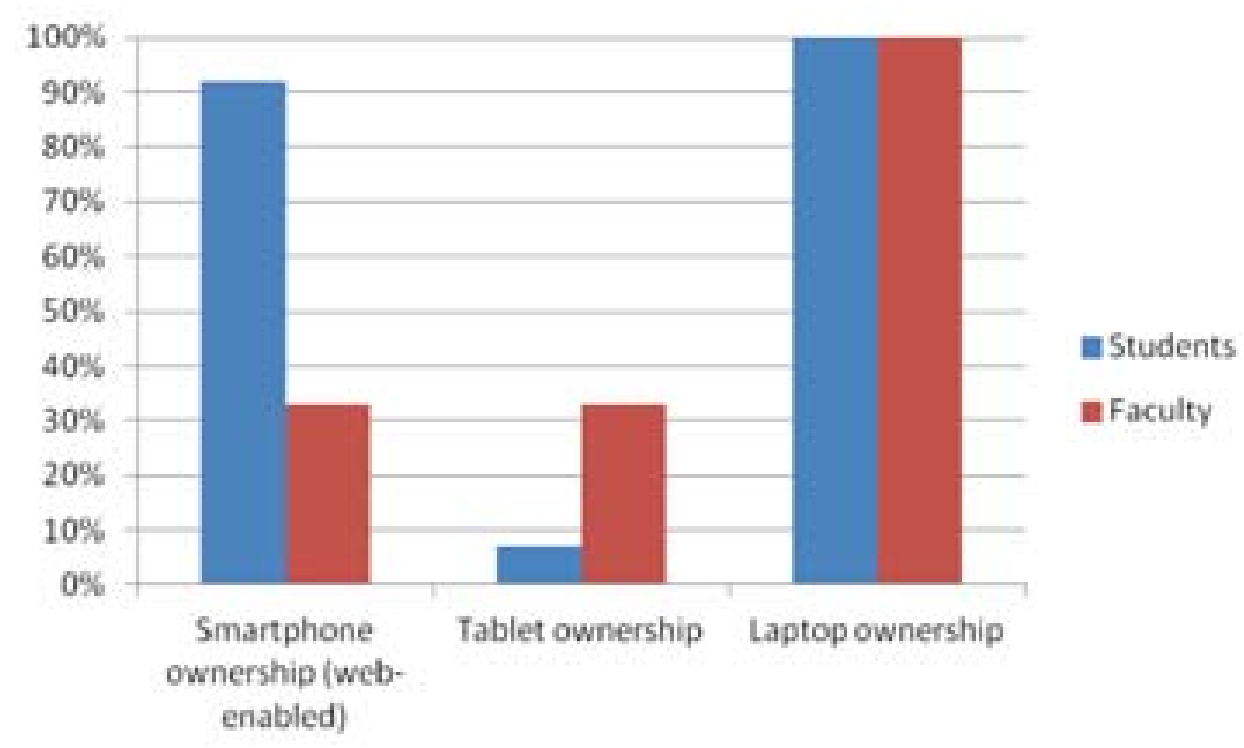

Figure 2. Student and faculty ownership of mobile devices

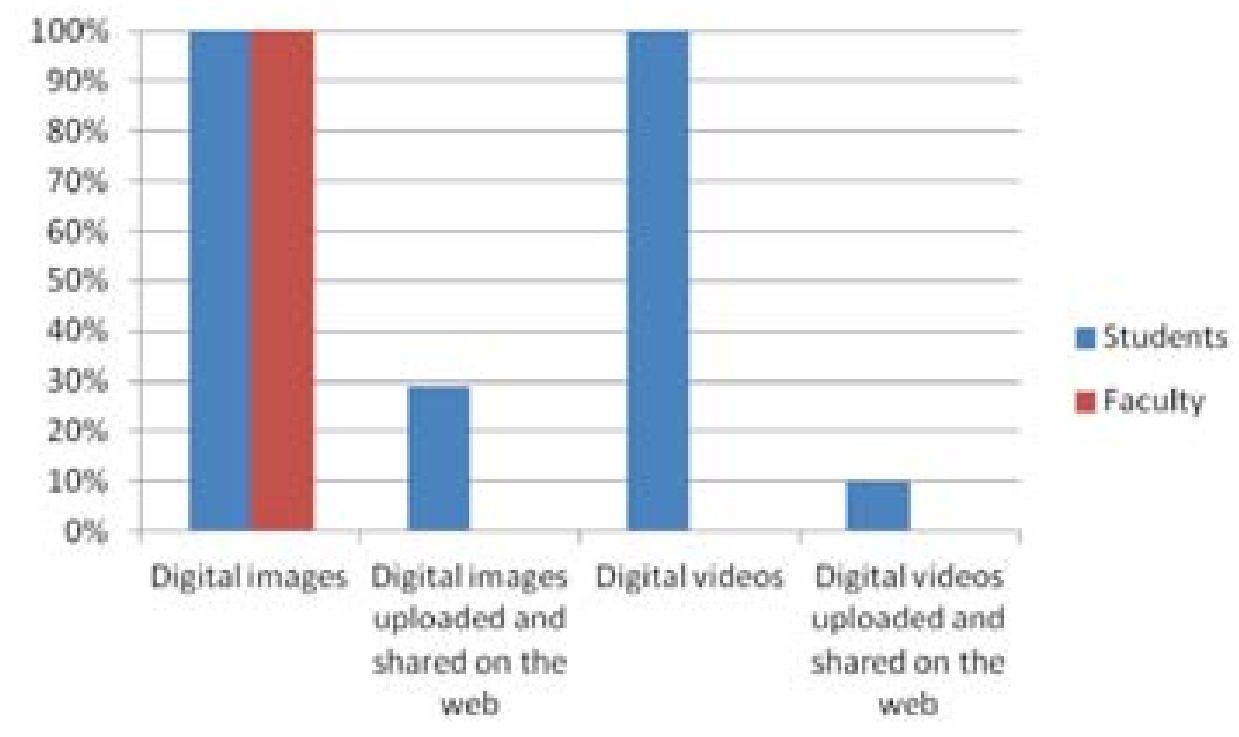

Figure 3. Student and faculty use of mobile devices

All of the students and faculty who participated in this study owned laptops; $92 \%$ of the students had smartphones, compared with only $33 \%$ of the faculty; and only 1 student (7\%) and 2 faculty members (33\%) had their own tablets. The students primarily used their mobile devices for communication and social networking, while the faculty members used these devices for academic purposes and navigation. The students also used their smartphones to capture and share digital images and videos, while the faculty were not familiar with how to perform these operations. The differences in student and faculty ownership and use of mobile devices are similar to the results of a study conducted at the University of Texas, Brownsville, where $94 \%$ of the students reported that they were ready for mobile learning, compared with only $60 \%$ of the faculty members (Corbeil \& Valdes-Corbeil, 2007). 


\section{Ability of Mobile Devices to Support Required Program Outcomes of a Pre- Service Teacher Education Program}

Alberta Education has created a draft of professional practice competencies for K-to12 teachers (Government of Alberta, 2011). These competencies consist of the following five categories:

1. Planning and preparation

2. Assessment

3. Facilitation

4. Classroom environment

5. Professional responsibilities

Students were asked in the pre- and post-study online surveys to rank and comment on how mobile devices (specifically tablets) could be used to help them achieve each of these five program outcomes. Faculty members were asked similar questions in their face-to-face interviews with the USRA. Both groups ranked professional responsibilities as the number one competency that could be supported through the use of mobile devices (Table 3). Students indicated in the post-course focus group that human contact was more important than computer-mediated communication when learning and practising professional responsibilities such as ethical behaviour. This is reflected in the post-study survey results, where only two-thirds of the students indicated that mobile devices were valuable for developing professional responsibilities.

Table 3

Professional Responsibilities

\begin{tabular}{|c|c|c|c|}
\hline & Faculty & $\begin{array}{c}\text { Student } \\
\text { pre-study }\end{array}$ & $\begin{array}{c}\text { Student } \\
\text { post-study }\end{array}$ \\
\hline $\begin{array}{l}\text { Valuable/ } \\
\text { very valuable }\end{array}$ & $83 \%$ & $93 \%$ & $64 \%$ \\
\hline $\begin{array}{l}\text { Related } \\
\text { comments }\end{array}$ & $\begin{array}{l}\text { "Tools of the } \\
\text { trade-important } \\
\text { to know 'first hand' } \\
\text { the pros and cons } \\
\text { of using mobile } \\
\text { devices in K to } 12 \\
\text { education." }\end{array}$ & $\begin{array}{l}\text { "It keeps you updated on the } \\
\text { current and emerging tech- } \\
\text { nology. As a future K to } 12 \\
\text { teacher this is very important } \\
\text { not only to keep you up to } \\
\text { date but to keep your class } \\
\text { engaged by using technology } \\
\text { that relates to their genera- } \\
\text { tion." }\end{array}$ & $\begin{array}{l}\text { "While using the } \\
\text { tablet, I found that I } \\
\text { had full access to the } \\
\text { internet. The internet } \\
\text { is the key when find- } \\
\text { ing information and } \\
\text { workshops to attend." }\end{array}$ \\
\hline
\end{tabular}


The second-highest-ranked competency was facilitating student learning. Both faculty and students commented that mobile devices could be used to facilitate different authentic learning pathways for K-to-12 students (Table 4). Again, the students in the post-course focus group emphasized the importance of human contact when facilitating learning; therefore there was a decrease in the percentage of students in the post-study survey who indicated that mobile devices are valuable for this program outcome.

Table 4

Facilitating Student Learning

\begin{tabular}{|c|c|c|c|}
\hline & Faculty & $\begin{array}{c}\text { Student } \\
\text { pre-study }\end{array}$ & $\begin{array}{c}\text { Student } \\
\text { post-study }\end{array}$ \\
\hline $\begin{array}{l}\text { Valuable/ } \\
\text { very valuable }\end{array}$ & $83 \%$ & $86 \%$ & $72 \%$ \\
\hline $\begin{array}{l}\text { Related } \\
\text { comments }\end{array}$ & $\begin{array}{l}\text { "Facilitating stu- } \\
\text { dent learning in } \\
\text { different ways- } \\
\text { making videos to } \\
\text { help students (ex: } \\
\text { philosophy, a math } \\
\text { probe)." }\end{array}$ & $\begin{array}{l}\text { "Every student has a unique } \\
\text { way of learning and by vary- } \\
\text { ing the method one uses to } \\
\text { teach, teachers can meet the } \\
\text { needs of more students." } \\
\text { "Mobile devices give us } \\
\text { so many different ways to } \\
\text { facilitate student learning. } \\
\text { There are computer games } \\
\text { designed for students to } \\
\text { work hands on with all dif- } \\
\text { ferent types of curriculum. } \\
\text { They also allow students } \\
\text { access to more sources then } \\
\text { just their teacher." }\end{array}$ & $\begin{array}{l}\text { "Tablets have given } \\
\text { me the opportunity to } \\
\text { include technology in a } \\
\text { more authentic way." } \\
\text { "I think we are in an } \\
\text { age that has put an } \\
\text { increasing emphasis on } \\
\text { hand-held technology } \\
\text { and it's only a matter } \\
\text { of time before children } \\
\text { are learning and com- } \\
\text { pleting homework on } \\
\text { them." }\end{array}$ \\
\hline
\end{tabular}


Initially, students and faculty were moderately positive about the ability of mobile devices to support the planning and preparation process for learning, but in the post-study survey, students commented on the technical restrictions and challenges of using tablets and smartphones to create lesson plans (Table 5).

Table 5

Planning and Preparing for Learning

\begin{tabular}{|c|c|c|c|}
\hline & Faculty & $\begin{array}{c}\text { Student } \\
\text { pre-study }\end{array}$ & $\begin{array}{c}\text { Student } \\
\text { post-study }\end{array}$ \\
\hline $\begin{array}{l}\text { Valuable/ } \\
\text { very valuable }\end{array}$ & $67 \%$ & $64 \%$ & $29 \%$ \\
\hline $\begin{array}{l}\text { Related } \\
\text { comments }\end{array}$ & $\begin{array}{l}\text { "Program of Stud- } \\
\text { ies Guides and } \\
\text { Resources are all } \\
\text { web-based-just a } \\
\text { click away." } \\
\text { "Caution: just be- } \\
\text { cause it's on the web } \\
\text { doesn't mean it's } \\
\text { valuable. Need to } \\
\text { look at and know it } \\
\text { is well researched." }\end{array}$ & $\begin{array}{l}\text { "Mobile devices are } \\
\text { essentially computers. } \\
\text { They allow teachers to } \\
\text { lesson plan anywhere in } \\
\text { the world. Teachers can } \\
\text { do research or search for } \\
\text { information at any time } \\
\text { during the day." }\end{array}$ & $\begin{array}{l}\text { "I prefer to lesson plan on a } \\
\text { laptop, computer, or net- } \\
\text { book because I have access } \\
\text { to a full keyboard. The tablet } \\
\text { is helpful when needing } \\
\text { to look over a plan that } \\
\text { you may have forgotten at } \\
\text { home." } \\
\text { "I don't feel like these de- } \\
\text { vices are efficient enough to } \\
\text { use for lesson planning... the } \\
\text { wi-fi is difficult to connect } \\
\text { to at times, and it's tricky to } \\
\text { type on. I'd much prefer to } \\
\text { do a lesson plan on a com- } \\
\text { puter." }\end{array}$ \\
\hline & & & $\begin{array}{l}\text { "I'm not sure that they } \\
\text { would be ideal for 'Planning } \\
\text { for Learning' because of the } \\
\text { small keyboard and screen. } \\
\text { I could see it becoming an- } \\
\text { noying." }\end{array}$ \\
\hline
\end{tabular}


In terms of the ability of mobile devices to be used to assess student learning, the faculty members were much more optimistic than the students. In both the pre- and the post-study surveys, students expressed concern about the emphasis on digital feedback, preferring a balance with oral and handwritten forms of assessment communication (Table 6).

Table 6

Assessing Student Learning

\begin{tabular}{|c|c|c|c|}
\hline & Faculty & $\begin{array}{l}\text { Student } \\
\text { pre-study }\end{array}$ & $\begin{array}{c}\text { Student } \\
\text { post-study }\end{array}$ \\
\hline $\begin{array}{l}\text { Valuable/ } \\
\text { very valuable }\end{array}$ & $83 \%$ & $50 \%$ & $23 \%$ \\
\hline $\begin{array}{l}\text { Related } \\
\text { comments }\end{array}$ & $\begin{array}{l}\text { "These devices can be used } \\
\text { to give richer feedback- } \\
\text { e.g., video tape the student } \\
\text { teachers doing the teach- } \\
\text { ing. And then sit down and } \\
\text { discuss video or can review } \\
\text { their research paper and } \\
\text { provide audio rather than } \\
\text { text-based feedback." } \\
\text { "Focus on process rather } \\
\text { than just product. Have } \\
\text { a video of a group work- } \\
\text { ing on things. Used to } \\
\text { tape grade ones reading } \\
\text { and let them listen to it to } \\
\text { see what they needed to } \\
\text { work on. Self-assessment. } \\
\text { Watch video of self (pre- } \\
\text { sentation)." }\end{array}$ & $\begin{array}{l}\text { "This will come in } \\
\text { handy if instead of } \\
\text { written comments, } \\
\text { students can see } \\
\text { their teacher or } \\
\text { peers evaluating } \\
\text { them through video } \\
\text { for example." } \\
\text { "This could be a } \\
\text { great way of input- } \\
\text { ting current grades } \\
\text { into electronic form, } \\
\text { especially if you are } \\
\text { out of town (not } \\
\text { near a computer) } \\
\text { or if your home } \\
\text { computer decides to } \\
\text { crash on you." }\end{array}$ & $\begin{array}{l}\text { "I find that hand } \\
\text { written feedback is } \\
\text { better when mark- } \\
\text { ing because it doesn't } \\
\text { make my eyes feel as } \\
\text { tired. I also prefer to } \\
\text { give oral feedback." } \\
\text { "No doubt hand-held } \\
\text { devices have a place } \\
\text { in innovative learn- } \\
\text { ing, but marking } \\
\text { homework/assign- } \\
\text { ments is probably not } \\
\text { where you'll see it." }\end{array}$ \\
\hline
\end{tabular}


Finally, both faculty and students expressed concern about the impact of mobile devices on the classroom environment. Both groups commented that these types of devices could become very distracting if not properly integrated into the learning process (Table 7).

Table 7 Classroom Environment

\begin{tabular}{|c|c|c|c|}
\hline & Faculty & $\begin{array}{l}\text { Student } \\
\text { pre-study }\end{array}$ & $\begin{array}{c}\text { Student } \\
\text { post-study }\end{array}$ \\
\hline $\begin{array}{l}\text { Valuable/ } \\
\text { very valuable }\end{array}$ & $33 \%$ & $29 \%$ & $7 \%$ \\
\hline $\begin{array}{l}\text { Related com- } \\
\text { ments }\end{array}$ & $\begin{array}{l}\text { "Distracting, kids online } \\
\text { when should be paying } \\
\text { attention." } \\
\text { "Can make it more com- } \\
\text { plex. Adding another } \\
\text { diversion." } \\
\text { "Potentially could help } \\
\text { manage learning envi- } \\
\text { ronment. Have more } \\
\text { personalized learning } \\
\text { environment: meaning- } \\
\text { ful projects, less disci- } \\
\text { pline problems." }\end{array}$ & $\begin{array}{l}\text { "Could be a distraction for } \\
\text { children." } \\
\text { "Could be a useful tool } \\
\text { because the students can } \\
\text { easily stay engaged using } \\
\text { various devices and there } \\
\text { are many different op- } \\
\text { tions when using technol- } \\
\text { ogy to control the class- } \\
\text { room." }\end{array}$ & $\begin{array}{l}\text { "I think that man- } \\
\text { aging the environ- } \\
\text { ment of a classroom } \\
\text { should be done by } \\
\text { the teacher not by a } \\
\text { device." } \\
\text { "I think that some } \\
\text { of the negative } \\
\text { behaviour can stem } \\
\text { from the use of } \\
\text { devices." }\end{array}$ \\
\hline
\end{tabular}

\section{Discussion and Recommendations}

The students in the post-study survey and focus group were asked to provide a series of recommendations and strategies for using mobile devices effectively in a blended preservice teacher education program. They have been grouped into five categories (Table 8).

The students indicated that educational design and personal choice were key elements to the successful use of mobile devices in a blended pre-service teacher education program. They emphasized that without a specific rationale for using these devices to support the intended learning outcomes of a course assignment or field-based learning experience, these digital tools could quickly become an expensive and frustrating distraction. They also recommended that institutional IT infrastructure needs to be in place in order to ensure the efficient use of mobile devices; this includes proper mobile apps, devices, and wireless internet connectivity in classrooms and laboratories.

In the post-study group, the student participants were also asked to comment on how they plan to use mobile devices in their future teaching practice. They emphasized that mobile devices should be used as digital tools by K-to-12 students for authentic, inquirybased project work. Many of the study participants had observed these devices primarily being used as e-books in their K-to-12 school placements, and they thought this was an expensive way for students to passively absorb yet more facts and information. 
Table 8

Recommendations and Strategies

\begin{tabular}{|c|c|}
\hline Recommendation & Strategy \\
\hline Educational design & $\begin{array}{l}\text { Specifically tie the use of mobile devices to course learning outcomes } \\
\text { and assignments. } \\
\text { "Perhaps we could incorporate activities and assignments into the } \\
\text { course that would force us to use our Tablet more. I found that it was } \\
\text { not needed in the classroom therefore I did not bring it with me or } \\
\text { use it very much at home either. We could have used the Voice Re- } \\
\text { corder for self and peer assessment feedback for each assignment." }\end{array}$ \\
\hline
\end{tabular}

Appropriate device for the appropriate task

Mobile apps

Tablet devices

Wireless internet connectivity
One size does not fit all when it comes to the appropriate use of mobile devices in a blended pre-service teacher education program. "I personally found my phone was more useful in school placements. It fit into my pocket, was easy to use to take video, pictures, and field notes. On the other hand, I find my laptop more valuable in our university classrooms as it allows me to easily take notes and search for information."

Ensure that key university apps are accessible. "It would be handy to have myUniversity as a compatible site with the tablet. From my experience, the myUniversity website doesn't work well/continues to freeze when trying to access my account." "Find a way to make Blackboard app available."

Use better-quality tablets or our own mobile devices. "Upgrade the tablets, use something of better quality."

Improve internet connectivity in the main university building. "Make sure everyone's device be connected to the internet easily in the classroom."

\section{Conclusion}

This research study was informed by Wenger's (1998) community of practice framework, which emphasizes three participatory dimensions: engagement, accountability, and negotiation. Engagement is dependent on developing an understanding of how to interact with other people within the community, such as students and faculty in preservice teacher education programs.

The results from this study demonstrate that students in pre-service teacher education programs potentially have more practical experience with mobile devices than faculty members. Thus, it is prudent for faculty to "listen and learn" from their students about how to use these devices effectively and efficiently.

Becoming accountable to an enterprise, for example a set of program outcomes, prompts members to consider certain possibilities that contribute to aligned perspectives 
of the world. With regard to the ability of mobile devices to support the learning outcomes of a BEd program, both faculty and student participants in this research study indicated that these digital tools could be useful for supporting future professional responsibilities (e.g., career-long learning, collaboration) and facilitating student learning but less effective for planning, assessment, and managing the classroom environment.

Wenger refers to negotiation as the ability to interpret and make use of a repertoire of the community's practice. This form of negotiation corresponds with the Māori concept of ako (Barlow, 2001). This term means both to teach and to learn. It recognizes the knowledge that both teachers and students bring to learning interactions, and it acknowledges the way that new knowledge and understandings can grow out of shared learning experiences, especially those that are mediated through the use of mobile devices. This concept has been supported by educational research showing that when teachers facilitate reciprocal teaching and learning roles in their classrooms, students' achievement improves (Alton-Lee, 2003). In addition, Hattie (2009) suggests that ako is the basis of a visible teaching and learning framework where "teachers SEE learning through the eyes of their students and students SEE themselves as their own teachers" (p. 238).

\section{Study Limitations}

The two major limitations of this study were the small sample size and the focus on selfreported data. The small sample size $(n=20)$ meant that significance is limited for the analysis of the quantitative survey data; thus, the results cannot be readily generalized or transferred to other pre-service teacher education programs. The surveys, interviews, and focus group conducted in this study all relied on self-reported data, which was limited by the fact that it was verified only by the co-authors of this study. These data may contain several potential sources of bias such as selective memory of the student and faculty participants (i.e., remembering or not remembering experiences or events that occurred at some point in the program) and exaggeration (i.e., the act of representing outcomes or embellishing events as more significant than is actually suggested from other data) (Brutus, 2013) .

\section{Further Research}

The findings from this study and the associated research literature (West, 2012) suggest that student ownership of mobile devices in higher education is steadily increasing and that students are expecting to use these devices to support their course and program assignments (BYOD-bring your own device). Thus, further research needs to be conducted in order to determine how students and faculty can effectively use these devices in blended environments to support learning inside and outside of the classroom.

\section{References}

Allen, I. E., \& Seaman, J. (2010). Class differences: Online education in the United States, 2010. Babson Survey Research Group, Sloan Consortium. Retrieved from http:// sloanconsortium.org/publications/survey/class_differences

Ally, M. (Ed.). (2009). Mobile learning: Transforming the delivery of education and training. Edmonton, AB: Athabasca University Press. Retrieved from http://www. aupress.ca/books/120155/ebook/99Z_Mohamed_Ally_2009-MobileLearning.pdf 
Alton-Lee, A. (2003). Quality teaching for diverse students in schooling: Best evidence synthesis. Wellington, New Zealand: Ministry of Education. Retrieved from http://www. educationcounts.govt.nz/publications/series/2515

Arabasz, P., Boggs, R., \& Baker, M. B. (2003). Highlights of e-learning support practices. Educause Center for Applied Research Bulletin, 9.

Barlow, C. (2001). Tikanga Whakaaro: Key concepts in Māori culture. South Melbourne, Australia: Oxford University Press.

Bleed, R. (2001). A hybrid campus for a new millennium. EDUCAUSE Review, 36(1), $16-24$.

Brasher, A., \& Taylor, J. (2005). Development of a research plan for use of ambient technology to test mobile learning theories. In J. Attewell \& C. Savill-Smith (Eds.), Mobile learning anytime everywhere (pp.33-37). London, UK: Learning and Skills Development Agency.

Brown, M., \& Diaz, V. (2010). Mobile learning: Context and prospects: A report on the ELI focus session. EDUCAUSE Learning Initiative. Retrieved from http://net.educause. edu/ir/library/pdf/ELI3022.pdf

Brutus, S. (2013). Self-reported limitations and future directions in scholarly reports: Analysis and recommendations. Journal of Management, 39(1), 48-75.

Clark, D. (2003). Blend it like Beckham. Brighton, UK: Epic Group PLC. Retrieved from http://www.epic.co.uk/content/resources/white_papers/blended.htm

Corbeil, J. R., \& Valdes-Corbeil, M. E. (2007). Are you ready for mobile learning? EDUCAUSE Quarterly, 3O(2), 51-58. Retrieved from http://net.educause.edu/ir/ library/pdf/EQM0726.pdf

Dziuban, C. D., \& Moskal, P. D. (2013). Blended learning: A dangerous idea? Internet and Higher Education, 18(7), 15-23.

Garnham, C., \& Kaleta, R. (2002). Introduction to hybrid courses. Teaching with Technology Today, 8(6). Retrieved from http://www.uwsa.edu/ttt/articles/garnham. htm

Garrison, D. R., \& Vaughan, N. D. (2008). Blended learning in higher education. San Francisco, CA: Jossey-Bass.

Gikas, J., \& Grant, M. M. (2013). Mobile computing devices in higher education: Student perspectives on learning with cellphones, smartphones \& social media. Internet and Higher Education, 19(2), 18-26.

Gilmore, T., Krantz, J., \& Ramirez, R. (1986). Action based modes of inquiry and the host-researcher relationship. Consultation: An International Journal, 5(3), 161.

Government of Alberta. (2011). Draft of professional practice competencies for teachers. Unpublished.

Graham, C. R. (2006). Blended learning systems: Definitions, current trends, and future directions. In C. Bonk \& C. Graham (Eds.), The handbook of blended learning: Global perspectives, local designs (pp. 3-21). San Francisco, CA: Pfeiffer. 
Hattie, J. (2009). Visible learning: A synthesis of over 800 meta-analyses relating to achievement. New York, NY: Routledge.

Kemmis, S. (2009). Action research as practice-based practice. Educational Action Research, 17(3), 463-474.

Lave, J., \& Wenger, E. (1991). Situated learning: Legitimate peripheral participation. Cambridge, UK: Cambridge University Press.

Littlejohn, A., \& Pegler, C. (2007). Preparing for blended e-learning. Connecting with E-learning series. London, UK: Routledge.

Matheos, K. (2011). Innovative practices research project: COHEREreport on blended learning. Ottawa, ON: Human Resources and Skills Development Canada. Retrieved from http://cohere.ca/wp-content/uploads/2011/11/REPORT-ON-BLENDED-LEARNINGFINAL1.pdf

Mayadas, F. A., \& Picciano, A. G. (2007). Blended learning and localness: The means and the end. Journal of Asynchronous Learning Networks, 11(1), 3-7.

Mobile Learning Network. (2013). The Mobile Learning Network. Retrieved from http://www.molenet.org.uk/

Norberg, A., Dziuban, C. D., \& Moskal, P. D. (2011). A time-based blended learning model. On the Horizon, 19(3), 207-216.

Patton, M. Q. (1990). Qualitative evaluation and research methods (2nd ed.). Newbury Park, CA: Sage Publications.

Pine, G. J. (2008). Teacher action research: Building knowledge democracies. Thousand Oaks, CA: Sage Publications.

Prairie Research Associates. (2011). Canadian university survey consortium: 2011 undergraduate university study survey results. Retrieved from http://www.cusc-ccreu.ca/ publications/CUSC_2011_UG_MasterReport.pdf

Sharpe, R., Benfield, G., Roberts, G., \& Francis, R. (2006). The undergraduate experience of blended e-learning: A review of UK literature and practice. London, UK: Higher Education Academy. Retrieved from http://www.heacademy.ac.uk/resources/ detail/teachingandresearch/Undergraduate_Experience

Stringer, E.T. (2007). Action research (3rd ed.). Thousand Oaks, CA: Sage Publications. Press.

Wenger, E. (1998). Communities of practice. Cambridge, UK: Cambridge University

West, M. (2012). Mobile learning for teachers: Global themes. UNESCO Working Paper Series on Mobile Learning. Paris: UNESCO. Retrieved from http://unesdoc. unesco.org/images/o021/o02164/216452e.pdf

Williams, C. (2002). Learning on-line: A review of recent literature in a rapidly expanding field. Journal of Further and Higher Education, 26(3), 263-272.

Williams, J. (2003). Blending into the background. E-Learning Age Magazine, 1. 
Zhu, E., Kaplan, M., Dershimer, C., \& Bergom, I. (2012). Using laptops in the classroom: The University of Michigan. Seeking Evidence of Impact (SEI) Case Studies. Boulder, CO: EDUCAUSE Learning Initiative. Retrieved from http://www.educause.edu/library/ resources/using-laptops-classroom-university-michigan

\section{Contact Information}

Norman Vaughan

Department of Education \& Schooling

Faculty of Teaching and Learning

Mount Royal University

nvaughan@mtroyal.ca

Norman Vaughan is an educator and researcher with interests in blended learning, faculty development and K to 12 schooling, Dr. Norm Vaughan is a Professor in the Department of Education, Faculty of Teaching and Learning at Mount Royal University in Calgary, Alberta. He is the co-author of the books Teaching in Blended Learning Environments: Creating and Sustaining Communities of Inquiry (2013) and Blended Learning in Higher Education (2008).

Kimberley Lawrence is a Bachelor of Education student and Vice President of the Education Student Association at the University of Calgary. Kim completed her Bachelor of Arts degree in English at Mount Royal University where she was also the President of the Education Undergraduate Society. 


\section{Appendix A: Pre-Course Student Online Survey Questions}

Important Note: The purpose of this survey is to gather student responses that will help inform the use of mobile devices in the Mount Royal University Education Program. Participation in this survey is voluntary and your responses will be kept confidential. Non-participation in this study will not jeopardize student progress in this EDUC2325: Understanding Current and Emerging Pedagogical Technologies course or the Education Program. Completion of the questionnaire below will constitute informed consent in this Role of Mobile Devices in a Blended Pre-Service Teacher Education Program? study. This study has been approved by the Mount Royal Human Research Ethics Board (HREB).

Name:

\section{Devices}

1. Do you own a mobile "hand held" device (e.g. iPhone, iTouch, Blackberry, Nokia, Motorola, LE, Samsung) that is web-enabled (e.g., can access web sites)?

2. If so, what kind of web sites do you utilize?

3. Do you own a mobile "hand held" device that can take digital pictures?

4. If so, what kind of pictures do you take and what do you do with these pictures?

5. Do you own a mobile "hand held" device that can take digital movies?

6. If so, what kind of videos do you take and what do you do with these videos?

7. What kind of mobile "hand held" device do you own (e.g. iPhone, iTouch, Blackberry, Nokia, Motorola, LE, Samsung)?

\section{Applications}

1. Do you have a Google Docs account?

2. Do you have a YouTube account?

3. Do you have a Blog account?

4. Do you have a Flickr account?

5. Do you have a Twitter account?

6. Do you have a Diigo account?

7. Do you have your own personal web site?

\section{B.Ed. Elementary Program}

1. How do you think mobile "hand held" devices could be used to support your learning in the B.Ed. Elementary program?

2. What do you think will be the educational advantages of using mobile "hand held" devices in this program?

3. What do you think will be the educational disadvantages of using mobile "hand held" devices in this program?

4. Any other comments or suggestions about using mobile "hand held" devices in this program? 
For your future $\mathrm{K}$ to 12 teaching career how valuable to do you think mobile "hand held" devices will be for performing the following tasks:

\begin{tabular}{|l|l|l|l|l|l|}
\hline Task & $\begin{array}{l}\text { Really not } \\
\text { valuable }\end{array}$ & $\begin{array}{l}\text { Not } \\
\text { valuable }\end{array}$ & $\begin{array}{l}\text { Not } \\
\text { sure }\end{array}$ & Valuable & $\begin{array}{l}\text { Really } \\
\text { valuable }\end{array}$ \\
\hline $\begin{array}{l}\text { Planning for learning (e.g., lesson } \\
\text { planning) }\end{array}$ & & & & \\
\hline $\begin{array}{l}\text { Facilitating student learning (e.g., dif- } \\
\text { ferent approaches to teaching) }\end{array}$ & & & & & \\
\hline $\begin{array}{l}\text { Assessing and evaluating student } \\
\text { learning (e.g., marking) }\end{array}$ & & & & & \\
\hline $\begin{array}{l}\text { Managing the learning environment } \\
\text { (e.g., classroom management) }\end{array}$ & & & & & \\
\hline $\begin{array}{l}\text { Working as a professional educator } \\
\text { (e.g., career-long learning) }\end{array}$ & & & & \\
\hline
\end{tabular}




\section{Appendix B: Faculty Interview Questions}

Important Note: The purpose of this interview is to gather faculty responses that will help inform the use of mobile devices in the Mount Royal University Education Program. Participation in this interview is voluntary and your responses will be kept confidential. Non-participation in this study will not jeopardize your employment at Mount Royal University. Please sign the informed consent form if you would like to participate in this Role of Mobile Devices in a Blended Pre-Service Teacher Education Program? study. You may withdraw from this study at any time and your data will be destroyed. This study has been approved by the Mount Royal Human Research Ethics Board (HREB).

Name:

\section{Devices}

1. Do you own a mobile "hand held" device (e.g. iPhone, iTouch, Blackberry, Nokia, Motorola, LE, Samsung) that is web-enabled (e.g., can access web sites)?

2. If so, what kind of web sites do you utilize?

3. Do you own a mobile "hand held" device that can take digital pictures?

4. If so, what kind of pictures do you take and what do you do with these pictures?

5 . Do you own a mobile "hand held" device that can take digital movies?

6. If so, what kind of videos do you take and what do you do with these videos?

7. What kind of mobile "hand held" device do you own (e.g. iPhone, iTouch, Blackberry, Nokia, Motorola, LE, Samsung)?

\section{B.Ed. Elementary Program}

1. How do you think mobile devices could be used to support student learning in our MRU B.Ed. Elementary Program?

2. What do you think could be the educational advantages of using mobile devices in our MRU B.Ed. Elementary Program?

3. What do you think could be the educational disadvantages of using mobile devices in our MRU B.Ed. Elementary Program?

4. For our students future $\mathrm{K}$ to 12 teaching careers how valuable to do you think mobile "hand held" devices will be for performing the following tasks: 


\begin{tabular}{|c|c|c|c|c|c|}
\hline Task & $\begin{array}{l}\text { Really not } \\
\text { valuable }\end{array}$ & $\begin{array}{l}\text { Not } \\
\text { valuable }\end{array}$ & $\begin{array}{l}\text { Not } \\
\text { sure }\end{array}$ & Valuable & $\begin{array}{l}\text { Really } \\
\text { valuable }\end{array}$ \\
\hline \multicolumn{6}{|l|}{$\begin{array}{l}\text { Planning for learning (e.g., lesson } \\
\text { planning) }\end{array}$} \\
\hline \multicolumn{6}{|l|}{ Please explain: } \\
\hline \multicolumn{6}{|l|}{$\begin{array}{l}\text { Facilitating student learning (e.g., } \\
\text { different approaches to teaching) }\end{array}$} \\
\hline \multicolumn{6}{|l|}{ Please explain: } \\
\hline \multicolumn{6}{|l|}{$\begin{array}{l}\text { Assessing and evaluating student } \\
\text { learning (e.g., marking) }\end{array}$} \\
\hline \multicolumn{6}{|l|}{ Please explain: } \\
\hline \multicolumn{6}{|l|}{$\begin{array}{l}\text { Managing the learning environment } \\
\text { (e.g., classroom management) }\end{array}$} \\
\hline \multicolumn{6}{|l|}{ Please explain: } \\
\hline \multicolumn{6}{|l|}{$\begin{array}{l}\text { Working as a professional educator } \\
\text { (e.g., career-long learning) }\end{array}$} \\
\hline Please explain: & & & & & \\
\hline
\end{tabular}

Any other comments or suggestions about using mobile devices in our MRU B.Ed. Elementary Program? 